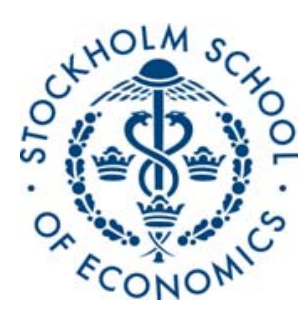

\title{
ESCAPING POLITICAL EXTRACTION: POLITICAL PARTICIPATION, INSTITUTIONS, AND CASH HOLDINGS IN CHINA
}

\author{
Xunan Feng \\ Shanghai Jiaotong University \\ Anders C. Johansson \\ Stockholm School of Economics \\ Harvard University
}

CERC Working Paper 18

March 2011

Postal address: P.O. Box 6501, S-113 83 Stockholm, Sweden.

Office address: Holländargatan 30 Telephone: +46 87369360 Telefax: +46 8313017

E-mail: japan@hhs.se Internet: http://www.hhs.se/cerc 


\title{
Escaping Political Extraction: Political Participation, Institutions, and Cash Holdings in China
}

\author{
Xunan Feng \\ Shanghai Jiaotong University \\ Anders C. Johansson ${ }^{*}$ \\ Stockholm School of Economics \\ Harvard University
}

March 2011

\footnotetext{
${ }^{*}$ Corresponding author, Stockholm School of Economics, P.O. Box 6501, SE-113 83 Stockholm, Sweden. Phone: +46-8-736 9367. Fax: +46-8-31 30 17. Email: anders.johansson@hhs.se. Johansson acknowledges financial support from the Bank of Sweden Tercentenary Foundation (RJ) and the Swedish Foundation for International Cooperation in Research and Higher Education (STINT).
} 


\title{
Escaping Political Extraction: Political Participation, Institutions, and Cash Holdings in China
}

\begin{abstract}
We study the effects of political participation on holdings of liquid assets in a transition economy. Previous research has shown that the risk of political extraction by politicians and bureaucrats in countries with weak institutions has an adverse effect on holdings of liquid assets. We propose that political participation by private entrepreneurs can function as a means to alleviate some of that risk. Our empirical results indicate that political participation is positively related to cash holdings in China, especially in regions with weak institutions proxied by lower GDP per capita, lower marketization levels, and weaker property protection. Cash holdings have a negative effect on firm value as measured by the market-to-book ratio. However, political participation, the combined effect of cash holdings and political participation, as well as the combined effect of cash holdings, political participation, and institutions are all positively associated with firm value. Political participation thus results in an improved ability for firms that function in an environment fraught with the risk of political extraction to increase their holdings of liquid assets as well as a related positive effect on firm value.
\end{abstract}

JEL Classification: G31; G32; G34; P48

Keywords: Political participation; Private entrepreneurs; Cash holdings; Political extraction; China 


\section{Introduction}

Research has shown that bureaucrats and politicians often extract rent from firms. This is especially true for firms in developing economies which face ambiguous property rights and poor legal protection. In extreme cases, the state itself becomes predatory, thereby creating a severe impediment to continued economic development. While many countries are perhaps not characterized by the predatory state phenomenon, firms still face the risk of political extraction. Previous studies have shown how the so-called grabbing hand distorts the domestic economy and creates problems for firms that would otherwise be successful (Shleifer and Vishny, 1993; Frye and Shleifer, 1997; Shleifer and Vishny, 1998). When the grabbing hand is particularly present, firms may take action to protect their assets from political extraction in different ways, including diversification and tax avoidance.

Caprio et al. (2008) analyze how firms structure their asset holdings in an attempt to avoid political extraction. They argue that such a strategy is likely to be most apparent in liquid asset choices. Since liquid assets are easier to steal than other assets such as property, plants, etc, they constitute a likely primary target for bureaucrats when they go after firm assets. Our paper extends this argument. We focus on how firms in China are influenced by the risk of political extraction. Our basic hypothesis is that firms with considerable political capital are less afraid to hold liquid assets such as cash. We test this by identifying private entrepreneurs who participate in politics. Through political participation, these entrepreneurs are able to develop strong 
relationships with fellow politicians and thus become less concerned with the risk of political extraction. This means that they will not have to resort to hiding assets to the same extent as private entrepreneurs without such strong political networks.

We propose two competing hypotheses for the influence of political participation on cash holdings. Besides the possibility that firms controlled by entrepreneurs who participate in politics exhibit larger cash holdings than other entrepreneurial firms due to better protection against political extraction, previous research indicates that political connections may actually result in lower levels of cash holdings. If this effect dominates the relationship between political participation and cash holdings, one would expect a negative relationship between the two. The relationship thus needs to be analyzed empirically.

Our results show that political participation by private entrepreneurs is indeed positively related to cash holdings in China. This indicates that political participation facilitates larger holdings of liquid assets. We believe that this finding is novel in that it adds a new dimension to the literature on political capital and rent seeking. The fact that political participation allows entrepreneurs to increase their firms' cash holdings means that their political capital results in a potential competitive advantage. Previous research has shown that there are optimal cash holdings levels for firms (e.g. Kim et al., 1998). If the risk of political extraction is so severe that firms are forced to maintain suboptimal levels of cash holdings, political participation may allow for entrepreneurial firms to maintain an optimal cash holding level while their competitors are unable to do so. 
We also find that institutions influence the effect that political participation has on cash holdings. In regions with low levels of economic development, low levels of marketization and weak property rights, political participation is a much more important determinant of cash holdings. In fact, when we include proxies for local institutions in the estimation, political participation on its own is no longer significant. Instead, political participation seems to work mainly through the interactive variable that combines institutions and political participation. We interpret this as political participation facilitating firms’ cash holdings in regions with weak institutions.

Finally, we discuss the economic effect of cash holdings, political connections, and local institutions on firm value. We document that political participation is positively associated with firm value, a result that is consistent with Feng et al. (2011) who show that entrepreneurial political participation greatly benefits firms. However, we find no evidence that cash holdings by themselves have a significant effect on firm value. On the other hand, the interaction effects between cash holdings and political participation as well as the simultaneous influence of cash holdings, local institutions dummy and political participation, all have a significant positive effect on firm value. This shows that political participation facilitates the holding of liquid assets, which in turn results in better firm performance. Overall, our results complement those of Caprio et al. (2008) in that we identify a way for firms to solve the problem with implicit restrictions on cash holdings, especially for firms that are active in regions marked by weaker institutions. 
The remainder of this paper is organized as follows. In Section 2, we develop testable hypotheses for the relation between political participation and cash holdings. Section 3 introduces the concept of private entrepreneurs who participate in politics in China and then discusses how we measure political participation. Section 4 first introduces the data set and then presents and discusses the empirical results. Finally, Section 5 concludes the study.

\section{Hypothesis Development and Relation to Prior Literature}

There are a number of theories and empirical studies on the determinants of cash holdings in the literature. Early research mainly focuses on the tradeoff between the cost of holding cash and the cost of running out of cash or, alternatively, whether the level of cash holdings is irrelevant and instead based on a simple financing hierarchy (Miller and Orr, 1966; Opler et al., 1999). More recent studies have identified other factors that may influence cash holdings. For example, Mikkelson and Partach (2003) study the relationship between cash holdings and stock ownership by insiders or institutional investors. Dittmar et al., (2003), Kalcheva and Lins, (2007) and Pinkowitz et al. (2003) further show that the level of protection of shareholder rights influence firms’ cash holdings decisions.

In addition to these factors, we suggest that strong ties to politicians through entrepreneurs’ political participation may influence cash holding decisions in countries with weak institutions. We put forward two competing hypotheses for the relationship between political participation and cash holdings. What we call the political extraction 
hypothesis focuses on the argument that firms in regions marked by weak institutions face a higher risk of political extraction. Since liquid assets are easier to extract, firms will protect themselves by decreasing their cash holdings (e.g. Caprio et al., 2008). Besides the often-used method of carrying out unofficial activities, firms can alleviate some of the risk of political extraction by developing close ties to politicians. ${ }^{1}$ While this approach most likely entails additional costs, it may enable the firm to work more efficiently, thus resulting in an overall positive effect on firm value. It has been shown in numerous studies that political connections have a significant positive effect on firm value, especially in countries with weak institutions (e.g. Fisman, 2001; Johnson and Mitton, 2003; Faccio, 2006; Faccio et al., 2006). We suggest that one possible benefit of private entrepreneurs' political participation is the access to political networks through which it is possible to decrease the risk of political extraction. If political ties are exploited this way, we thus expect that political participation is positively associated with cash holdings.

What can be called the capital access theory, on the other hand, suggests that the relationship between political participation and cash holdings is very different. Related studies have shown that private entrepreneurs are able to exploit their political networks to gain preferential access to capital (e.g. Johnson and Mitton, 2003; Khwaja

\footnotetext{
${ }^{1}$ One alternative way for firms in developing countries to escape corruption and the grabbing hand is to increase their unofficial activities, thus making it more difficult for bureaucrats to extract rent from them (e.g. Johnson et al., 1998; Johnson et al., 2000; Friedman et al., 2000).
} 
and Mian, 2005), and that firms with good access to capital markets usually hold less cash (Opler et al., 1999). If this effect is strong, it may dominate the political extraction effect and we can thus expect a negative correlation between political participation and cash holdings. To identify the dominant effect in the relationship between political participation and cash holdings, we therefore have to resort to empirical analysis. We put forward the following competing hypotheses:

Hypothesis 1 a (the political extraction argument): Political participation by the controlling private entrepreneur is positively associated with cash holdings

Hypothesis $1 b$ (the capital access argument): Political participation by the controlling private entrepreneur is negatively associated with cash holdings

In a related study, Caprio et al. (2008) document that cash holdings are also associated with the quality of institutions, in their case measured by several proxies for corruption. They find that a higher level of corruption results in smaller cash holdings, which helps reducing the grabbing hand effect. Since our political extraction hypothesis is based on the assumption that political participation may play a more important role for escaping political extraction when weaker institutions are present, we put forward the following hypothesis:

Hypothesis 2: The effects of political participation on cash holdings are related to local institutions as proxied by economic development, marketization, and property rights 
Finally, we focus on the direct effects of cash holdings and political participation on firm value. Previous research has shown that political participation by private entrepreneurs in China is positively associated with firm value (Feng et al., 2011). However, research on the effect of cash holdings on firm value has not shown a definitive general relationship. Due to its importance for firms in China, political participation may influence the relationship between cash holdings and firm value as well as the relationship between institutions and firm value. We thus suggest the following hypotheses:

Hypothesis 3: Political participation by the controlling private entrepreneur is positively associated with firm value

Hypothesis 4: The effects of cash holdings on firm value are related to political participation

Hypothesis 5: The effects of institutions on cash holdings are related to political participation

\section{Political Participation by Private Entrepreneurs and Institutions}

\subsection{Identifying Political Participation}

Having experienced long periods of discrimination during the initial phase of China's economic reforms, private firms are becoming increasingly important for the 
Chinese economy. ${ }^{2}$ This study focuses on private entrepreneurs that decide to participate in politics. In our sample, we follow the related literature and identify shareholders who control more than $10 \%$ of the outstanding shares of a company and are listed as the ultimate controlling shareholder (La Porta et al., 1999; Bortolotti and Faccio, 2009).

To control for indirect political participation, we also consider the possibility that a member of the private entrepreneur's family participates in politics. As a proxy for political participation, we use membership in one of three key state entities: the Congress of the Chinese Communist Party (CCCP), the National People's Congress (NPC), and the Chinese People's Political Consultative Conference (CPPCC). We also include participation at the provincial level in each of the three entities. We believe that such a position serves well as a proxy for political participation. The CCCP is held once every five years and can be seen as the highest body within the Chinese Communist Party (CCP). The NPC formally acts as the highest organ of the state and functions as the country's legislative body, while the CPPCC functions as a political advisory body that is comprised of members from different parties and organizations as well as individuals.

\footnotetext{
${ }^{2}$ According to Tsai (2007), there were about 30 million registered private companies in China in 2005. This accounted for circa half of China’s GDP. Dougherty et al. (2007) document how private firms’ share of total industrial product increased from 25\% in 1998 to over 50\% in 2003.
} 


\subsection{Rent-Seeking Opportunities and the Benefits of Political Participation}

Previous research has found that local institutions are related to the level of rent-seeking opportunities in a country. In the literature on corruption and the grabbing hand phenomenon, it has been shown that rent seeking and corruption are associated with lower economic development (e.g., Baumol, 1990; Murphy et al., 1991; Mauro, 1995; Shleifer and Vishny, 1993). For example, Hall and Jones (1999) and Acemoglu et al. (2001) document how institutions are associated with cross-country variations in income. Previous studies have also focused on how strong property rights and an effective rule of law limit rent seeking. We expand our analysis on the influence of political participation on holdings of liquid assets with three different proxies for local institutions to find more robust results.

Economic development is often used when analyzing issues such as the grabbing hand, corruption, and political connections. For example, Treisman (2000) shows that lower economic development is related to higher corruption. In her study on political connections, Faccio (2006) also uses GDP per capita as a simple proxy for local institutions. Therefore, we use the same approach in this paper and divide the firms into two groups based on whether their headquarters are located in a province with high and low GDP per capita, respectively. 
We also use the National Economic Research Institute (NERI) Index of Marketization $^{3}$ for China's provinces to proxy for local institutions because more developed markets can improve local institutions in a transition economy such as China (Wang et al, 2007). We thus divide the sample into two groups based on the level of marketization. Finally, to analyze the impact of local differences in property rights’ protection, we use a World Bank survey from 2006 that focuses on China's larger cities (World Bank, 2006). The entrepreneurial firms are thus divided into two groups depending on whether or not their headquarters are located in places with relatively higher levels of property protection. Summing up, low real GDP per capita, low levels of marketization, and weak property rights should be conducive for rent seeking. Following hypothesis 2 above, we expect the effect of political participation on the size of cash holdings to be significantly influenced by local institutions.

\footnotetext{
${ }^{3}$ The NERI index focuses on provinces' progress towards a market economy relative to other provinces. Each province is given a score between zero and ten. The index is based on 23 indicators of institutional arrangements and policies in five areas: size of the regional government; economic structure (growth of the non-state sector and the reform of state-controlled firms); inter-regional trade barriers; development of factor markets; and the legal framework (Wang et al., 2007).
} 


\section{Empirical Analysis}

\subsection{Data and Sample Description}

We manually collect data on private entrepreneurs and their political participation for all listed firms on the two stock exchanges in China. To avoid problems with potential differences in accounting methods, we focus on firms that have only issued A-shares. ${ }^{4}$ We extract financial data for all firms from the China Security Market and Accounting Research (CSMAR) database. We then delete observations with missing data, negative equity, etc. To minimize potential effects due to IPOs or reverse mergers, we also require the firms to be listed for at least two years to be included in the data set. Listed firms in China disclose cash and short-term securities on their balance sheets since 1990. However, their cash flow statements, which include cash and cash-equivalent posts, were not disclosed until 1998 when new regulations were issued by the Ministry of Finance. Our sample therefore covers the period 1999-2009.

Table 1 provides a description of the data sample. The first column presents the total number of firms that have listed A-shares and no B-shares, while the second

\footnotetext{
${ }^{4}$ Chinese firms have been listing A- and B-shares, which differ from each other based on investor brackets. Domestic investors are allowed to trade A-shares, while B-shares have traditionally been traded by foreign investors. As a result of a share reform in 2001, domestic investors are allowed to trade in B-shares. Only a minority of the listed firms in Shanghai and Shenzhen have issued B-shares.
} For more information on different share classes and share-class reforms, see Chan et al., (2007, 2008). 
column shows the number of these firms that are controlled by a private entrepreneur. Column three presents the total number of firms that are controlled by private entrepreneurs in our final sample, and column 4 shows the sample firms as a percentage of all listed firms that have only issued A-shares. Panel A shows that the number of firms controlled by private entrepreneurs was modest during the beginning of the sample, but that such firms have come to constitute an increasingly large share of the total number of listed firms in China. The total number of listed firms in the sample grew from 822 in 1999 to 1,570 in 2009, while the total number of listed firms controlled by private entrepreneurs increased from 71 to 659 during the same period. In total, we have 13,221 observations for all A-share firms. After deleting firm observations with missing accounting data or negative equity, our final sample consists of 2,115 (out of a total of 3,424 ) observations for firms controlled by private entrepreneurs.

Panel B in Table 1 presents the distribution of firms controlled by private entrepreneurs who participate in politics. The number of such firms increased from a modest 9 to 173 during the sample period. The share of the total number of firms controlled by private entrepreneurs grew from $23 \%$ to $44 \%$ during 1999-2009, a change that is likely at least partly a result of an increasing number of private entrepreneurs realizing the benefits of participating in politics. In our final sample, we thus have a total of 2,115 firms controlled by private entrepreneurs and 868 observations of firms controlled by entrepreneurs who participate in politics. 


\subsection{Political Participation and Cash Holdings}

We begin the empirical analysis by focusing on how political participation by controlling entrepreneurs affects holdings in liquid assets. We first use univariate tests to look at differences in cash holdings depending on whether or not the controlling private entrepreneur is participating in politics. For robustness, we use three different definitions of cash holdings: the ratio of cash and cash equivalents to total assets; the ratio of cash and cash equivalents to total assets minus cash and cash equivalents; the ratio of cash to total assets. Table 2 presents univariate tests for differences in the mean and median of cash holdings for the two groups of privately controlled firms. In two out of the three cases, the mean of cash holdings for firms controlled by private entrepreneurs who participate in politics is significantly larger than that of other privately controlled firms. For all three definitions of cash holdings, the median of cash holdings for firms controlled by entrepreneurs who participate in politics is significantly larger than that of other entrepreneurial firms. The initial between-group tests thus indicate that political participation is positively associated with cash holdings.

To obtain more robust results on the relationship between political participation by private entrepreneurs and firms' cash holdings, we run several different forms of regressions, including a pooled ordinary least square (OLS) regression, a Tobit regression, and a fixed effect regression. For the OLS regression, we report robust $t$ statistics. We include a Tobit regression to take the potential issue of censored dependent variables into account. Finally, the fixed-effect model takes firm-specific 
effects into account. The dependent variable is the ratio of cash and cash equivalents to total assets. ${ }^{5}$ The main independent variable is political participation, a dummy variable that is equal to one if the controlling private entrepreneur is participating in politics and zero otherwise. We also include a number of control variables found in the literature on determinants of cash holdings: sales growth, measured as the difference in the natural logarithm of sales between years $t$ and $t$-1; financial leverage measured as the ratio of short- and long-term debt to total assets; firm size, measured as the natural logarithm of total assets; profitability, measured as the return on assets (ROA); operating cash flow, measured as the ratio of cash flow from operations to total assets; change in net working capital, measured as the change in the ratio of net working capital over total assets; investment, measured as the change in fixed assets plus inventory over total assets; ownership rights, measured as entrepreneurial cash-flow rights; control minus ownership, measured as the difference between entrepreneurial control rights and cash-flow rights; and finally industry and year dummies for the OLS and Tobit regressions. In the fixed effect model, ownership rights and control minus ownership are not included since such data is only available for 2009. Because firms’ ownership structures generally change slowly, we assume that these two ownership

\footnotetext{
${ }^{5}$ For brevity, we only provide the regression results using the ratio of cash and cash equivalents to total assets as dependent variable. The results are similar when using the alternative measures for cash holdings as dependent variable.
} 
variables are constant. To reduce the effect of outliers, we also winsorize the variables at the top and bottom 5\%.

Table 2 presents the results of the three different regressions. Regardless of which type of regression we use, the coefficient for political participation remains significant and positive. This shows that political participation is positively associated with cash holdings, a result that supports the political extraction hypothesis. If the capital access theory were to dominate the political extraction theory, we would expect the coefficient to be negative and significant. Overall, firms with controlling private entrepreneurs who participate in politics tend to hold more cash, indicating that political participation results in important political networks which in turn enable firms to increase their holdings of liquid assets without fearing political extraction.

\subsection{The Influence of Local Institutions}

To better understand how local institutions affect the relationship between political participation and cash holdings, we run new regressions in which we include the proxies for rent-seeking opportunities discussed in Section 3.2. We first focus our analysis on economic development and divide the sample into two groups based on the GDP per capita of the provinces where the headquarters of the firms are located. We then run new between-group tests in each of the two subsamples to see how economic development affects the relationship between political participation and cash holdings.

Panel A in Table 3 presents the results for the between-group mean and median tests. It is evident that economic development has a significant effect on the influence 
of political participation on cash holdings. In provinces with low GDP per capita, the effect of political participation on cash holdings is strong, resulting in larger cash holdings for firms with political participation. When we divide the sample based on whether or not the controlling private entrepreneur participates in politics, we find no significant difference in cash holdings for firms located in provinces with high GDP per capita. These initial results indicate that economic development influences the positive effect political participation has on cash holdings.

When we instead use marketization and property rights as proxies for local institutions, the results are similar. Panel B shows that when we divide firms based on political participation by the controlling entrepreneur, there is no significant effect in regions where the level of marketization is high. When the level of marketization is low, firms controlled by entrepreneurs who participate in politics hold significantly more cash. Similarly, Panel C in Table 3 shows that cash holdings of firms controlled by entrepreneurs who participate in politics is significantly larger in provinces with poorer property rights, while there is no difference in provinces with stronger property rights.

To further control for the possible influence of other factors, we again run multivariate regressions. We use pooled OLS regressions, Tobit regressions, and Logistic transformation regressions to find more robust results. The dependent variable is once more the ratio of cash and cash equivalents to total assets ${ }^{6}$. We include all

\footnotetext{
${ }^{6}$ The results are similar when we use the alternative measures for cash holdings as dependent variable.
} 
control variables used in the previous regressions as well as local institutions dummies. We focus on the interaction effect of political participation and the institutions proxy to find how the two interact together to influence firms' cash holding decisions.

Table 4 reports the regression results. The institutions dummy in the regressions presented in Panel A is economic development. The results show that when we take local institutions and the interactive variable of political participation and local institutions into account, the coefficient for political participation becomes smaller and insignificant. The coefficient for institutions is highly significant and negative, an expected result since the institutions dummy is equal to one for provinces with low economic development. Finally, the interactive variable is positive and significant regardless of which form of regression we use. Panels B and C present the alternative regressions with marketization and property rights as proxies for institutions. The results are similar to those in Panel A, with the coefficient for political participation positive but not significant, the coefficient for institutions negative and significant, and the interactive variable between political participation and institutions positive and significant.

Overall, the results in Table 4 show how important institutions are for firms in China. More importantly, they also show that local differences in institutions influence the effect that political participation has on the size of cash holdings in private firms. While the impact of political participation on its own becomes insignificant, the interactive variable that combines institutions and political participation is highly significant in all three alternative regressions. The empirical results in Tables 3 and 4 
thus highlight that political participation mainly contributes to increased cash holdings in regions marked by weak local institutions. This finding again supports the theory that political participation by private entrepreneurs and the resulting political networks can be utilized to mitigate risk when the firm functions in an environment marked by a higher risk for political extraction.

\subsection{The Value of Cash Holdings}

So far, our results indicate that entrepreneurs' political participation greatly influences private firms' cash holding decisions, especially in regions with weaker institutions. In this subsection, we further discuss its economic effects on firm value. Looking at how cash holdings, political participation, and institutions affect firm value is important for at least two reasons. Firstly, if investors perceive that entrepreneurial political participation can reduce bureaucratic political extraction, then the value they place on firms' cash holdings should increase accordingly. Confirming the existence of such a relationship would complement the results in the last section. Secondly, looking at firm value of the interaction effects, we may find a specific mechanism through which political participation functions, thereby contributing to the literature on political connections.

We estimate pooled OLS regressions with market-to-book value as the dependent variable. Our focus is cash holdings, political participation, and institutions, and their interactive variables. To once more control for the possible influence of other 
factors, we add a series of control variables similar to the ones used in the previous section.

The regression results are presented in Table 5. The table consists of three panels with the three different proxies for institutions. For each setup of independent variables, we again use three alternative measures for liquid assets: the ratio of cash and cash equivalent assets to total assets; the ratio of cash and cash equivalents to total assets minus cash and cash equivalents; and the ratio of cash to total assets. Panel A presents the result with GDP per capita as the institutions dummy. Several findings are worth noticing. First, cash holdings have a significant negative impact on the marketto-book ratio. Second, political participation is positively associated with market value. Third, the coefficient for the interactive variable cash holding*political participation is significant and positive, indicating that political participation works through the holdings of liquid assets. Fourth, the coefficient for the interactive variable of political participation and institutions is also positive and significant. Fifth, the coefficient for the interactive variable that combines all three of these factors is significant and positive. Panels $\mathrm{B}$ and $\mathrm{C}$ in Table 5 present results that are very similar to those of Panel A. Although cash holdings on its own is again a negative influence on market value, political participation and all the interactive variables that include political participation are all positively associated with the market-to-book ratio. These results are robust regardless of which definition we use for liquid assets in all of the three panels. 
The results in Table 5 show how important political participation is for firm value. It also shows that cash holdings as an independent variable has a negative influence on firm value, but that firms controlled by private entrepreneurs who participate in politics exhibit a positive relationship between firm value and the interaction between local institutions and cash holdings. This indicates that entrepreneurs are able to expand their cash holdings and use them to increase firm value. Furthermore, local institutions do not affect firm value independently from other factors. Instead, private entrepreneurs who participate in politics are able to exploit rent-seeking opportunities in areas with low GDP per capita, low levels of marketization, and weak property protection.

\section{Conclusion}

This study documents how firms controlled by private entrepreneurs who participate in politics are able to increase firm competitiveness and value. Our initial results indicate that holdings of liquid assets are positively associated with political participation by the controlling entrepreneur. When we add local institutions, we find that the positive effect of political participation on cash holdings is important in areas with poor institutions. This supports the political extraction hypothesis, which states that firms controlled by entrepreneurs who participate in politics will hold more cash because of the lower risk of political extraction as a result of ties to leading politicians. These results complement those of Caprio et al. (2008), who show that firms hold less cash holdings in countries with weaker institutions. We also find that political 
participation has a positive influence on firm value. Our results support the findings in earlier studies that politically connected firms are able to exploit rent-seeking opportunities, especially in economies marked by weak institutions. We also find that cash holdings have a negative effect on firm value, but that the interactive variable composed of cash holdings and political participation is positively associated with firm value. These findings indicate that firms are able to exploit their entrepreneurs' political connections and benefit from optimal cash holdings strategies that normal entrepreneurial firms cannot use.

Our results underline that cash holdings are important for firms in transition economies, but that the risk of political extraction makes it difficult for firms to pursue optimal strategies that focus on the holdings of liquid assets. One way to mitigate the risk of political extraction is for the controlling private entrepreneur to participate in politics, and the resulting political connections decrease the risk of local bureaucrats or politicians extracting rent from the company. We believe that our results are useful when analyzing the behavior of entrepreneurial firms and how they deal with the risk of political extraction in other transition economies. 


\section{References}

Acemoglu, D., Johnson, S., Robinson, J., 2001. The colonial origins of comparative development: an empirical investigation. American Economic Review 91, 1369-1401.

Baumol, W., 1990. Entrepreneurship: productive, unproductive, and destructive. Journal of Political Economy 98, 893-921.

Bortolotti, B., Faccio, M., 2009. Government control of privatized firms. Review of Financial Studies 22, 2907-2939.

Caprio, L., Faccio, M., McConnell, J.J., 2008. Sheltering corporate assets from political extraction. Working Paper, Purdue University.

Chan, K., Menkveld, A.J., Yang, Z., 2007. The informativeness of domestic and foreign investors' stock trades: Evidence from the perfectly segmented Chinese market. Journal of Financial Markets 10, 391-415.

Chan, K., Menkveld, A.J., Yang, Z., 2008. Information asymmetry and asset prices: Evidence from the China foreign share discount. Journal of Finance 63, 159-196.

Dittmar, A., Mahrt-Smith, J., Servaes, H., 2003. International corporate governance and corporate cash holdings. Journal of Financial and Quantitative Analysis 38, 111133.

Dougherty, S., Herd, R., He, P., 2007. Has a private sector emerged in China’s industry? Evidence from a quarter of a million Chinese firms. China Economic Review 18, 309-334. 
Faccio, M., 2006. Politically connected firms. American Economic Review 96, 369386.

Faccio, M., Masulis, R.W., McConnell, J.J., 2006. Political connections and corporate bailouts. Journal of Finance 61, 2597-2635.

Feng, X., Johansson, A.C., Zhang, T., 2011. Political participation and entrepreneurial initial public offerings in China. China Economic Research Center Working Paper Series No. 17, Stockholm School of Economics.

Fisman, R., 2001. Estimating the value of political connections. American Economic Review 91, 1095-1102.

Friedman, E., Johnson, S., Kaufmann, D., Zoido-Lobatón, P., 2000. Dodging the grabbing hand: the determinants of unofficial activity in 69 countries. Journal of Public Economics 76, 459-493.

Frye, T., Shleifer, A., 1997. The invisible hand and the grabbing hand. American Economic Review, Papers and Proceedings 87, 354-358.

Hall, R., Jones, C., 1999. Why do some countries produce so much more output per worker than others? Quarterly Journal of Economics 114, 83-116.

Johnson, S., Kaufmann, D., McMillan, J., Woodruff, C., 2000. Why do firms hide? Bribes and unofficial activity after communism. Journal of Public Economics 76. 495520.

Johnson, S., Kaufmann, D., Zoido-Lobatón, P., 1998. Regulatory discretion and the unofficial economy. American Economic Review, Papers and Proceedings 88, 387-392. 
Johnson, S., Mitton, T., 2003. Cronyism and Capital Controls: evidence from Malaysia. Journal of Financial Economics 67, 351-382.

Kalcheva, I., Lins, K.V., 2007. International evidence on cash holdings and expected managerial agency problems. Review of Financial Studies 20, 1087-1112.

Khwaja, A., Mian, A., 2005. Do lenders favor politically connected firms? Rent provision in an emerging financial market. Quarterly Journal of Economics 120, 13711411.

Kim, Chang-Soo, Mauer, D.C., Sherman, A.E., 1998. The determinants of corporate liquidity: theory and evidence. Journal of Financial and Quantitative Analysis 33, 335-359.

La Porta, R., Lopez-de-Silanes, F., Shleifer, A., 1999. Corporate ownership around the world. Journal of Finance 54, 471-518.

Mauro, P., 1995. Corruption and growth. Quarterly Journal of Economics 110, 681711.

Mikkelson, W.H., Partch, M.M., 2003. Do persistent large cash reserves hinder performance? Journal of Financial and Quantitative Analysis 38, 275-294.

Miller, M.H., Orr, D., 1966. A model of the demand for money by firms. Quarterly Journal of Economics 80, 413-435.

Murphy, K.M., Shleifer, A., Vishny, R.W., 1991. The allocation of talent: Implications for growth. Quarterly Journal of Economics 106, 503-530. 
Opler, T., Pinkowitz, T., Stulz, R., Williamson, R., 1999. The determinants and implications of corporate cash holdings. Journal of Financial Economics 52, 3-46.

Pinkowitz, L., Stulz, R.M., Williamson, R., 2003. Do firms in countries with poor protection of investor rights hold more cash? NBER Working Paper No. 10188.

Shleifer, A., Vishny, R.W., 1993. Corruption. Quarterly Journal of Economics 108, 599-617.

Shleifer, A., Vishny, R.W., 1998. The grabbing hand: government pathologies and their cures. Cambridge, MA: Harvard University Press.

Treisman, D., 2000. The causes of corruption: a cross-national study. Journal of Public Economics 76, 399-457.

Tsai, K.S., 2007. Capitalism without democracy: The private sector in contemporary China. Ithaca, NY: Cornell University Press.

Wang, X., Fan, G., Zhu, H., 2007. Marketisation in China: progress and contribution to growth, in: Garnaut, R., Song, L. (Eds) China linking markets for growth. Canberra: ANU E Press and Asia Pacific Press.

World Bank, 2006. China: governance, investment climate, and harmonious society: competitiveness enhancements for 120 cities in China. Report No. 37750-CN. 


\section{Table 1. Sample}

\section{Panel A: Distribution of entrepreneurial firms}

This panel presents the distribution of entrepreneurial sample firms by year between 1999-2009. A-share firms are ones that have only issued A-shares on one of China's stock exchanges. Entrepreneurial firms refer to firms controlled by private entrepreneurs or their families. Sample firms are the firms included in our study after deleting missing data or observations with negative equities.

\begin{tabular}{cccccc}
\hline & & Number of & & \multicolumn{2}{c}{ Sample Firms } \\
\cline { 1 - 3 } \cline { 5 - 5 } Year & $\begin{array}{c}\text { Number of } \\
\text { A-share firms }\end{array}$ & $\begin{array}{c}\text { total } \\
\text { entrepreneurial } \\
\text { Firms }\end{array}$ & & Number & $\begin{array}{c}\text { As percentage of } \\
\text { all listed A-share } \\
\text { firms }\end{array}$ \\
2099 & 822 & 71 & & 4.74 \\
2001 & 955 & 96 & & 60 & 6.28 \\
2002 & 1025 & 119 & & 79 & 7.71 \\
2003 & 1085 & 152 & & 95 & 8.76 \\
2004 & 1146 & 213 & & 124 & 10.82 \\
2005 & 1236 & 291 & & 163 & 13.19 \\
2006 & 1240 & 324 & & 216 & 17.42 \\
2007 & 1287 & 404 & & 245 & 19.04 \\
2008 & 1396 & 519 & & 320 & 22.92 \\
2009 & 1459 & 576 & & 383 & 26.25 \\
Total & 1570 & 659 & 391 & 24.90 \\
& 13221 & 3424 & & 2115 & 16.00 \\
\hline
\end{tabular}




\section{Table 1. Sample (Continued)}

\section{Panel B: Distribution of entrepreneurial firms and political participation}

This panel presents the distribution of sample firms controlled by private entrepreneurs who participate in politics. Political participation is defined as the controlling entrepreneur (or his/her family members) being a member of the National People's Congress (NPC), Chinese People's Political Consultative Conference (CPPCC), the Congress of the Chinese Communist Party (CCCP), or any of their provincial counterparts at the end of the fiscal year.

\begin{tabular}{lccc}
\hline & & \multicolumn{2}{c}{$\begin{array}{c}\text { Firms controlled by entrepreneurs who participate } \\
\text { in politics }\end{array}$} \\
\cline { 3 - 4 } Year & $\begin{array}{c}\text { Number of } \\
\text { sample firms }\end{array}$ & Numbers & $\begin{array}{c}\text { As percentage of } \\
\text { sample firms }\end{array}$ \\
\cline { 3 - 4 } 1999 & 39 & 9 & 23.08 \\
2000 & 60 & 14 & 23.33 \\
2001 & 79 & 19 & 24.05 \\
2002 & 95 & 23 & 24.21 \\
2003 & 124 & 58 & 46.77 \\
2004 & 163 & 77 & 47.24 \\
2005 & 216 & 99 & 45.83 \\
2006 & 245 & 106 & 43.27 \\
2007 & 320 & 121 & 37.81 \\
2008 & 383 & 169 & 44.13 \\
2009 & 391 & 173 & 44.25 \\
Total & 2115 & 868 & 41.04 \\
\hline
\end{tabular}


Table 2. Effect of political participation on cash holdings

\section{Panel A: Univariate Tests}

This panel presents univariate tests for cash holding in firms controlled by private entrepreneurs, sorted by whether or not the controlling entrepreneur participates in politics. The ratio of cash and cash equivalents to total assets, the ratio of cash and cash equivalents to total assets minus cash and cash equivalents, the ratio of cash to total assets are all included for robustness. T-test and the Wilcoxon-Mann-Whitney test are alternately provided for the difference in the mean and median of cash holdings for entrepreneurial firms with and without political participation. ***, **, and $*$ denote significance at $1 \%, 5 \%$, and $10 \%$, respectively.

\begin{tabular}{lccc}
\hline & $\begin{array}{c}\text { Ratio of cash and } \\
\text { cash equivalents } \\
\text { to total assets }\end{array}$ & $\begin{array}{c}\text { Ratio of cash and } \\
\text { cash equivalents to } \\
\text { total assets minus } \\
\text { cash and cash } \\
\text { equivalents }\end{array}$ & $\begin{array}{c}\text { Ratio of cash to } \\
\text { total assets }\end{array}$ \\
\hline Mean & $\begin{array}{c}\text { Mean } \\
\text { (Median) }\end{array}$ & $\begin{array}{c}\text { Mean } \\
\text { (Median) }\end{array}$ \\
\hline Political participation & $0.172^{*}$ & 0.227 & $0.169^{*}$ \\
Observations & $(0.156)^{* *}$ & $(0.185)^{* *}$ & $(0.153)^{* *}$ \\
\hline No political participation & 868 & 868 & 868 \\
\hline Observations & 0.168 & & 0.163 \\
\hline
\end{tabular}




\section{Table 2. Effect of political participation on cash holdings (Continued)}

\section{Panel B: Multivariate analysis}

This table presents results from regressions in which the dependent variable is defined as the ratio of cash and cash equivalent to total assets. The independent variables include: Political participation, which equals one if the controlling entrepreneur participates in politics and zero otherwise; Sales growth, measured as the difference in the natural logarithm of sales between year $t$ and year $t-1$; Financial leverage, measured as the ratio of the sum of short term debt and long term debt to total assets; Size, measured as the natural logarithm of total assets; Profitability, measured as the return on assets (ROA); Operating cash flow, measured as the ratio of cash flow from operations to total assets; Delta NWC / assets, measured as the change in net working capital over total assets; Investment / assets, measured as the change in fixed assets and inventory over total assets; Ownership rights, measured as entrepreneurial cash-flow rights; Control minus ownership, measured as the difference between entrepreneurial control rights and cash-flow rights. Industry and year dummies are also included but not reported. The pooled OLS regression in model (1) is applied with robust $t$ statistics which are given in parentheses. The Tobit model in model (2) is used due to the censored dependent variable. The fixed effect model in model (3) is provided to take potential firm-specific effects into account. All variables are winsorized at the top and bottom 5\%.***,**, and * denote significance at $1 \%, 5 \%$, and $10 \%$, respectively. 
Table 2. Effect of political participation on cash holdings (Continued)

Panel B: Multivariate analysis

\begin{tabular}{|c|c|c|c|}
\hline & Pooled OLS & Tobit & Fixed effect \\
\hline Political participation & $\begin{array}{l}0.004^{*} \\
(1.76)\end{array}$ & $\begin{array}{l}0.004^{*} \\
(1.77)\end{array}$ & $\begin{array}{l}0.003^{*} \\
(1.84)\end{array}$ \\
\hline Sales growth & $\begin{array}{c}0.011^{* *} \\
(2.43)\end{array}$ & $\begin{array}{c}0.011^{* *} \\
(2.44)\end{array}$ & $\begin{array}{l}0.007^{*} \\
(2.07)\end{array}$ \\
\hline Financial leverage & $\begin{array}{c}-0.212 * * * \\
(-11.29)\end{array}$ & $\begin{array}{c}-0.212^{* * *} \\
(-11.38)\end{array}$ & $\begin{array}{c}-0.1110^{* *} \\
(-4.95)\end{array}$ \\
\hline Firm size & $\begin{array}{l}0.003 \\
(1.03)\end{array}$ & $\begin{array}{l}0.003 \\
(1.04)\end{array}$ & $\begin{array}{l}0.041 * * * \\
\quad(6.89)\end{array}$ \\
\hline Profitability & $\begin{array}{c}0.393 * * * \\
(4.73)\end{array}$ & $\begin{array}{c}0.393 * * * \\
(4.77)\end{array}$ & $\begin{array}{c}0.177 * * \\
(2.31)\end{array}$ \\
\hline $\begin{array}{l}\text { Operating cash flow/ } \\
\text { assets }\end{array}$ & $\begin{array}{l}-0.009 \\
(-0.28)\end{array}$ & $\begin{array}{l}-0.009 \\
(-0.28)\end{array}$ & $\begin{array}{l}0.036 \\
(1.23)\end{array}$ \\
\hline Delta NWC/ assets & $\begin{array}{c}-0.139 * * * \\
(-5.86)\end{array}$ & $\begin{array}{c}-0.139 * * * \\
(-5.90)\end{array}$ & $\begin{array}{c}-0.095 * * * \\
(-5.20)\end{array}$ \\
\hline Investment/ assets & $\begin{array}{c}-0.097 * * * \\
(-4.50)\end{array}$ & $\begin{array}{c}-0.097 * * * \\
(-4.54)\end{array}$ & $\begin{array}{c}-0.141^{* * *} \\
(-7.98)\end{array}$ \\
\hline Cash-flow rights & $\begin{array}{c}0.036 * * \\
(2.31)\end{array}$ & $\begin{array}{c}0.037 * * * \\
(2.32)\end{array}$ & No \\
\hline $\begin{array}{l}\text { Control minus } \\
\text { Ownership }\end{array}$ & $\begin{array}{c}0.061^{* *} \\
(2.40)\end{array}$ & $\begin{array}{c}0.061^{* *} \\
(2.42)\end{array}$ & No \\
\hline Intercept & $\begin{array}{l}0.027 \\
(0.38)\end{array}$ & $\begin{array}{l}0.027 \\
(0.38)\end{array}$ & $\begin{array}{c}-0.733 * * * \\
(-5.91)\end{array}$ \\
\hline $\begin{array}{l}\text { Industry indicators } \\
\text { Year indicators }\end{array}$ & $\begin{array}{l}\text { Yes } \\
\text { Yes }\end{array}$ & $\begin{array}{l}\text { Yes } \\
\text { Yes }\end{array}$ & $\begin{array}{l}\text { No } \\
\text { No }\end{array}$ \\
\hline $\begin{array}{l}\text { Observations } \\
\text { Adjusted } R^{2}\end{array}$ & $\begin{array}{l}2115 \\
0.184\end{array}$ & 2115 & 2115 \\
\hline Sigma & & $\begin{array}{c}0.096 \\
(65.04)\end{array}$ & \\
\hline $\begin{array}{l}\text { F test for no fixed } \\
\text { effects }\end{array}$ & & & 6.55 \\
\hline$R^{2}$ & & & 0.690 \\
\hline
\end{tabular}




\section{Table 3. Univariate tests for entrepreneurial cash holdings and local institutions}

This table reports univariate tests for entrepreneurial cash holdings on subsamples partitioned by local factors. Cash holdings 1 is the ratio of cash and cash equivalent to total assets. Cash holdings 2 is the ratio of cash and cash equivalents to total assets minus cash and cash equivalents. Cash holdings 3 is the ratio of cash to total assets. $T$-tests and the Wilcoxon-Mann-Whitney tests are alternately provided for the difference in the mean and median of entrepreneurial cash holdings for firms controlled by private entrepreneurs that participate in politics and common entrepreneurial firms. All variables are winsorized at the top and bottom 5\%. ${ }^{* * *}$, **, and * denote significance at $1 \%$, $5 \%$, and $10 \%$, respectively.

In panel A, the sample is partitioned by the sample median value of local GDP per capita. In panel B, the sample is partitioned by whether or not the firm's headquarter is located in a more developed region, using the sample median value of the National Economic

Research Institute (NERI) Index of Marketization for China's provinces. In panel C, the sample is partitioned by the level of property protection, based on a survey by the World Bank (2006).

\begin{tabular}{|c|c|c|c|c|c|c|}
\hline & \multicolumn{3}{|c|}{ High rent-seeking opportunities } & \multicolumn{3}{|c|}{ Low rent-seeking opportunities } \\
\hline \multicolumn{7}{|c|}{ Panel A: Real GDP per capita } \\
\hline Cash holdings 1 & $\begin{array}{c}0.165^{* * *} \\
(0.152)^{* * *}\end{array}$ & $\begin{array}{c}0.145 \\
(0.118)\end{array}$ & 0.020 & $\begin{array}{c}0.175 \\
(0.155)\end{array}$ & $\begin{array}{c}0.177 \\
(0.154)\end{array}$ & -0.002 \\
\hline Cash holdings 2 & $\begin{array}{c}0.216^{* *} \\
(0.180)^{* * *}\end{array}$ & $\begin{array}{c}0.191 \\
(0.134)\end{array}$ & 0.025 & $\begin{array}{c}0.230 \\
(0.184)\end{array}$ & $\begin{array}{c}0.242 \\
(0.183)\end{array}$ & -0.011 \\
\hline
\end{tabular}


Table 3: Univariate tests for entrepreneurial cash holdings and local institutions (Continued)

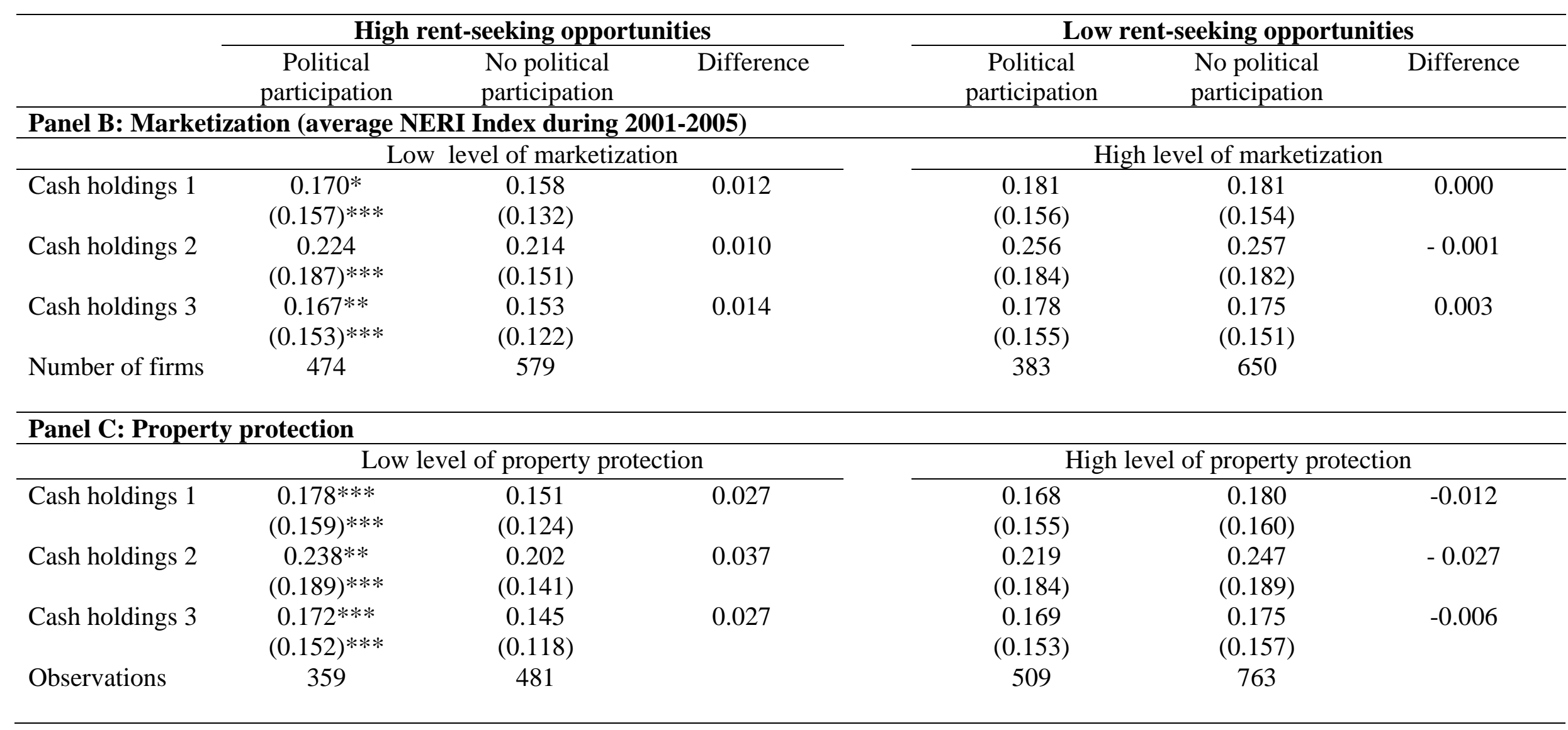




\section{Table 4. Entrepreneurial cash holdings and local institutions}

This table presents the regression results of the effects of political participation on entrepreneurial cash holdings, sorted by local institutions. The dependent variable in this table is measured as the ratio of cash and cash equivalents to total assets. The independent variables include: Political participation, which equals one if the controlling entrepreneur participates in politics and zero otherwise; Sales growth, measured as the difference in the natural logarithm of sales between year $t$ and year $t-1$; Financial leverage, measured as the ratio of the sum of short term debt and long term debt to total assets; Size, measured as the natural logarithm of total assets; Profitability, measured as the return on assets (ROA); Operating cash flow, measured as the ratio of cash flow from operations to total assets; Delta NWC / assets, measured as the change in net working capital over total assets; Investment / assets, measured as the change in fixed assets and inventory over total assets; Ownership rights, measured as entrepreneurial cash-flow rights; Control minus ownership, measured as the difference between entrepreneurial control rights and cash-flow rights. Industry and year dummies are also included but not reported. Model (1) is estimated with a pooled OLS regression. Robust $t$ statistics are given in parentheses. Model (2) is estimated with a Tobit regression to take censored dependent variable into account. Model (3) is estimated with a logistic transformation regression in which the dependent variable $z_{i}$ is computed as $z_{i}=\ln \left(y_{i} /\left(1-y_{i}\right)\right)$. Here, $y_{i}$ is the ratio of cash and cash equivalent to total assets are also provided. All variables are winsorized at the top and bottom 5\%. ***, **, and $*$ denote significance at $1 \%, 5 \%$, and $10 \%$, respectively. 
Table 4. Entrepreneurial cash holdings and local institutions (Continued)

\section{Panel A: GDP per capita}

In this panel, the institutions dummy is proxied by local GDP per capita, measured as above or below the sample median value of local average real GDP per capita during 1979-2007. If local GDP per capita in the province where the firm's headquarter is located is below the sample median value, the institutions proxy is equal to one and zero otherwise.

\begin{tabular}{|c|c|c|c|}
\hline & Pooled OLS & Tobit & $\begin{array}{c}\text { Logistic } \\
\text { transformation }\end{array}$ \\
\hline Political participation & $\begin{array}{l}-0.001 \\
(-1.38)\end{array}$ & $\begin{array}{l}-0.001 \\
(-1.39)\end{array}$ & $\begin{array}{l}-0.038 \\
(-0.73)\end{array}$ \\
\hline Institutions & $\begin{array}{c}-0.032 * * * \\
(-5.75)\end{array}$ & $\begin{array}{c}-0.032 * * * \\
(-5.74)\end{array}$ & $\begin{array}{c}-0.318 * * * \\
(-6.67)\end{array}$ \\
\hline $\begin{array}{l}\text { Political participation* } \\
\text { institutions }\end{array}$ & $\begin{array}{c}0.021 * * * \\
(3.26)\end{array}$ & $\begin{array}{c}0.021^{* * *} \\
(3.29)\end{array}$ & $\begin{array}{c}0.241 * * * \\
(3.64)\end{array}$ \\
\hline Sales growth & $\begin{array}{l}0.013 * * \\
(2.18)\end{array}$ & $\begin{array}{c}0.013^{* *} \\
(2.19)\end{array}$ & $\begin{array}{c}0.128 * * \\
(2.00)\end{array}$ \\
\hline Financial leverage & $\begin{array}{c}-0.210^{* * *} \\
(-11.11)\end{array}$ & $\begin{array}{c}-0.208^{* * * *} \\
(-11.20)\end{array}$ & $\begin{array}{c}-1.303^{* * *} \\
(-8.41)\end{array}$ \\
\hline Firm size & $\begin{array}{l}-0.001 \\
(-0.31)\end{array}$ & $\begin{array}{l}0.001 \\
(0.40)\end{array}$ & $\begin{array}{l}0.0307 \\
(1.29)\end{array}$ \\
\hline Profitability & $\begin{array}{l}0.414 * * * \\
\quad(5.45)\end{array}$ & $\begin{array}{c}0.414^{* * *} \\
(4.89)\end{array}$ & $\begin{array}{l}3.329 * * * \\
(5.29)\end{array}$ \\
\hline $\begin{array}{l}\text { Operating cash flow/ } \\
\text { assets }\end{array}$ & $\begin{array}{l}-0.008 \\
(-0.28)\end{array}$ & $\begin{array}{l}-0.009 \\
(-0.24)\end{array}$ & $\begin{array}{l}0.004 \\
(0.01)\end{array}$ \\
\hline Delta NWC/ assets & $\begin{array}{c}-0.136 * * * \\
(-5.80)\end{array}$ & $\begin{array}{c}-0.136 * * * \\
(-5.85)\end{array}$ & $\begin{array}{c}-0.950 * * * \\
(-4.90)\end{array}$ \\
\hline Investment/ assets & $\begin{array}{c}-0.106 * * * \\
(-4.87)\end{array}$ & $\begin{array}{c}-0.106 * * * \\
(-4.59)\end{array}$ & $\begin{array}{c}-0.652 * * * \\
(-3.61)\end{array}$ \\
\hline Ownership rights & $\begin{array}{l}0.028^{*} \\
(1.83)\end{array}$ & $\begin{array}{l}0.028^{*} \\
(1.84)\end{array}$ & $\begin{array}{l}0.100^{*} \\
(0.77)\end{array}$ \\
\hline Control minus ownership & $\begin{array}{c}0.061^{* *} \\
(2.43)\end{array}$ & $\begin{array}{c}0.061^{* *} \\
(2.45)\end{array}$ & $\begin{array}{c}0.426 * * \\
(2.04)\end{array}$ \\
\hline Intercept & $\begin{array}{c}0.140^{* *} \\
(2.31)\end{array}$ & $\begin{array}{c}0.140 * * \\
(2.33)\end{array}$ & $\begin{array}{c}-2.960^{* * *} \\
(-5.89)\end{array}$ \\
\hline Industry indicator & Yes & Yes & Yes \\
\hline Year indicator & Yes & Yes & Yes \\
\hline $\begin{array}{l}\text { Observations } \\
\text { Adjusted } R^{2}\end{array}$ & $\begin{array}{l}2115 \\
0.197\end{array}$ & 2115 & $\begin{array}{l}2115 \\
0.161\end{array}$ \\
\hline Sigma & & $\begin{array}{c}0.096 * * * \\
(65.04)\end{array}$ & \\
\hline
\end{tabular}


Table 4. Entrepreneurial cash holdings and local institutions (Continued)

\section{Panel B: Marketization}

In this panel, the institutions dummy is proxied by whether or not the firm's headquarter is located in a relatively more developed region, using the National Economic Research Institute (NERI) Index of Marketization for China's provinces. If the firm's headquarter is located in a less developed region, the institutions dummy is equal to one and zero otherwise.

\begin{tabular}{|c|c|c|c|}
\hline & Pooled OLS & Tobit & $\begin{array}{c}\text { Logistic } \\
\text { transformation }\end{array}$ \\
\hline Political participation & $\begin{array}{l}-0.002 \\
(-0.74)\end{array}$ & $\begin{array}{l}-0.002 \\
(-0.75)\end{array}$ & $\begin{array}{l}-0.008 \\
(-0.16)\end{array}$ \\
\hline Institutions & $\begin{array}{c}-0.016 * * * \\
(-2.82)\end{array}$ & $\begin{array}{c}-0.016^{* * *} \\
(-2.84)\end{array}$ & $\begin{array}{c}-0.189 * * * \\
(-4.03)\end{array}$ \\
\hline $\begin{array}{l}\text { Political participation* } \\
\text { institutions }\end{array}$ & $\begin{array}{c}0.012^{*} \\
(1.76)\end{array}$ & $\begin{array}{l}0.012^{*} \\
(1.77)\end{array}$ & $\begin{array}{c}0.159 * * \\
(2.20)\end{array}$ \\
\hline Sales growth & $\begin{array}{c}0.012^{* *} \\
(2.08)\end{array}$ & $\begin{array}{c}0.012 * * \\
(2.10)\end{array}$ & $\begin{array}{l}0.123^{*} \\
(1.91)\end{array}$ \\
\hline Financial leverage & $\begin{array}{c}-0.215^{* * *} \\
(-11.30)\end{array}$ & $\begin{array}{c}-0.215^{* * *} \\
(-11.50)\end{array}$ & $\begin{array}{c}-1.344^{* * *} \\
(-8.63)\end{array}$ \\
\hline Firm size & $\begin{array}{l}0.001 \\
(0.83)\end{array}$ & $\begin{array}{l}0.001 \\
(0.84)\end{array}$ & $\begin{array}{l}0.041^{*} \\
(1.75)\end{array}$ \\
\hline Profitability & $\begin{array}{l}0.414^{* * *} \\
\quad(5.41)\end{array}$ & $\begin{array}{l}0.414^{* * *} \\
(5.45)\end{array}$ & $\begin{array}{l}3.332 * * * \\
(5.26)\end{array}$ \\
\hline $\begin{array}{l}\text { Operating cash flow/ } \\
\text { assets }\end{array}$ & $\begin{array}{l}-0.011 \\
(-0.29)\end{array}$ & $\begin{array}{l}-0.011 \\
(-0.29)\end{array}$ & $\begin{array}{l}-0.014 \\
(-0.05)\end{array}$ \\
\hline Delta NWC/ assets & $\begin{array}{c}-0.137 * * * \\
(-5.81)\end{array}$ & $\begin{array}{c}-0.137 * * * \\
(-5.86)\end{array}$ & $\begin{array}{c}-0.957 * * * \\
(-4.90)\end{array}$ \\
\hline Investment/ assets & $\begin{array}{c}-0.106^{* * *} \\
(-4.82)\end{array}$ & $\begin{array}{c}-0.106^{* * * *} \\
(-4.86)\end{array}$ & $\begin{array}{c}-0.649 * * * \\
(-3.57)\end{array}$ \\
\hline Ownership rights & $\begin{array}{c}0.033^{* *} \\
(2.05)\end{array}$ & $\begin{array}{c}0.033^{* *} \\
(2.07)\end{array}$ & $\begin{array}{c}0.132^{* *} \\
(2.27)\end{array}$ \\
\hline Control minus ownership & $\begin{array}{c}0.063^{* *} \\
(2.47)\end{array}$ & $\begin{array}{c}0.063^{* *} \\
(2.48)\end{array}$ & $\begin{array}{c}0.441^{* *} \\
(2.11)\end{array}$ \\
\hline Intercept & $\begin{array}{l}0.103 \\
(1.69)\end{array}$ & $\begin{array}{l}0.103^{*} \\
(1.70)\end{array}$ & $\begin{array}{c}-3.252^{* * *} \\
(-6.46)\end{array}$ \\
\hline $\begin{array}{l}\text { Industry indicator } \\
\text { Year indicator }\end{array}$ & $\begin{array}{l}\text { Yes } \\
\text { Yes }\end{array}$ & $\begin{array}{l}\text { Yes } \\
\text { Yes }\end{array}$ & $\begin{array}{l}\text { Yes } \\
\text { Yes }\end{array}$ \\
\hline $\begin{array}{l}\text { Observations } \\
\text { Adiusted } R^{2}\end{array}$ & $\begin{array}{l}2115 \\
0.187\end{array}$ & 2115 & 2115 \\
\hline $\begin{array}{l}\text { Aajusted K } \\
\text { Sigma }\end{array}$ & $0.18 /$ & $\begin{array}{c}0.096 * * * \\
(65.04)\end{array}$ & \\
\hline
\end{tabular}


Table 4. Entrepreneurial cash holdings and local institutions (Continued)

\section{Panel C: Property protection}

In this panel, the institutions dummy is proxied by whether or not the firm's headquarter is located in a province that has a higher level of property protection based on a World Bank field survey (World Bank, 2006). If the firm's headquarter is located in a province that has a lower level of property protection, the institutions dummy is equal to one and zero otherwise.

\begin{tabular}{|c|c|c|c|}
\hline & Pooled OLS & Tobit & $\begin{array}{c}\text { Logistic } \\
\text { transformation }\end{array}$ \\
\hline Political participation & $\begin{array}{l}-0.007 \\
(-1.10)\end{array}$ & $\begin{array}{l}-0.007 \\
(-1.11)\end{array}$ & $\begin{array}{l}-0.014 \\
(-0.30)\end{array}$ \\
\hline Institutions & $\begin{array}{c}-0.012 * * \\
(-2.13)\end{array}$ & $\begin{array}{c}-0.012 * * \\
(-2.16)\end{array}$ & $\begin{array}{c}-0.133^{* * * *} \\
(-2.75)\end{array}$ \\
\hline $\begin{array}{l}\text { Political participation* } \\
\text { institutions }\end{array}$ & $\begin{array}{c}0.022^{* *} \\
(2.52)\end{array}$ & $\begin{array}{c}0.022 * * \\
(2.54)\end{array}$ & $\begin{array}{c}0.189 * * * \\
(2.58)\end{array}$ \\
\hline Sales growth & $\begin{array}{l}0.011^{*} \\
(1.82)\end{array}$ & $\begin{array}{l}0.011^{*} \\
(1.84)\end{array}$ & $\begin{array}{l}0.112 * \\
(1.74)\end{array}$ \\
\hline Financial leverage & $\begin{array}{c}-0.211 * * * \\
(-11.17)\end{array}$ & $\begin{array}{c}-0.211^{* * *} \\
(-11.25)\end{array}$ & $\begin{array}{c}-1.311^{* * * *} \\
(-8.38)\end{array}$ \\
\hline Firm size & $\begin{array}{l}0.001 \\
(0.45)\end{array}$ & $\begin{array}{l}0.001 \\
(0.45)\end{array}$ & $\begin{array}{l}0.052 \\
(1.20)\end{array}$ \\
\hline Profitability & $\begin{array}{l}0.412 * * * \\
(5.38)\end{array}$ & $\begin{array}{l}0.412^{* * *} \\
(5.43)\end{array}$ & $\begin{array}{l}3.309 * * * \\
(5.22)\end{array}$ \\
\hline $\begin{array}{l}\text { Operating cash flow/ } \\
\text { assets }\end{array}$ & $\begin{array}{l}-0.008 \\
(-0.23)\end{array}$ & $\begin{array}{l}-0.008 \\
(-0.23)\end{array}$ & $\begin{array}{l}-0.000 \\
(-0.01)\end{array}$ \\
\hline Delta NWC/ assets & $\begin{array}{c}-0.136 * * * \\
(-5.73)\end{array}$ & $\begin{array}{c}-0.136^{* * *} \\
(-5.77)\end{array}$ & $\begin{array}{c}-0.939 * * * \\
(-4.79)\end{array}$ \\
\hline Investment/ assets & $\begin{array}{c}-0.135 * * * \\
(-4.50)\end{array}$ & $\begin{array}{c}-0.135^{* * * *} \\
(-4.80)\end{array}$ & $\begin{array}{c}-0.650 * * * \\
(-3.56)\end{array}$ \\
\hline Ownership rights & $\begin{array}{c}0.035^{* *} \\
(2.22)\end{array}$ & $\begin{array}{c}0.035^{* *} \\
(2.22)\end{array}$ & $\begin{array}{c}0.157 * * \\
(2.19)\end{array}$ \\
\hline Control minus ownership & $\begin{array}{c}0.064 * * \\
(2.53)\end{array}$ & $\begin{array}{c}0.064^{* *} \\
(2.55)\end{array}$ & $\begin{array}{c}0.448 * * \\
(2.13)\end{array}$ \\
\hline Intercept & $\begin{array}{l}0.082 \\
(1.38)\end{array}$ & $\begin{array}{l}0.082 \\
(1.39)\end{array}$ & $\begin{array}{c}-3.514 * * * \\
(-7.06)\end{array}$ \\
\hline Industry indicator & Yes & Yes & Yes \\
\hline Year indicator & Yes & Yes & Yes \\
\hline $\begin{array}{l}\text { Observations } \\
\text { Adjusted } R^{2}\end{array}$ & $\begin{array}{l}2115 \\
0.187\end{array}$ & 2115 & $\begin{array}{l}2115 \\
0.146\end{array}$ \\
\hline Sigma & & $\begin{array}{c}0.096^{* * *} \\
(65.04)\end{array}$ & \\
\hline
\end{tabular}




\section{Table 5. The value of entrepreneurial cash holdings}

This table presents the regression results of the value of entrepreneurial cash holdings. The dependent variable is a firm's market-to-book ratio. The independent variables include: Cash holdings, alternately measured as the ratio of cash and cash equivalents to total assets in model (1), the ratio of cash and cash equivalent to total assets minus cash and cash equivalent in model (2), and the ratio of cash to total assets in model (3); Political participation, which equals one if the controlling entrepreneur participates in politics and zero otherwise; the institutions dummy; the interaction of cash holdings and political participation; the interaction of political participation and institutions; the interaction of cash holdings, political participation, and institutions; Sales growth, measured as the difference in the natural logarithm of sales between year $t$ and year $t-1$; Financial leverage, measured as the ratio of the sum of short term debt and long term debt to total assets; Size, measured as the natural logarithm of total assets; Profitability, measured as the return on assets (ROA); Ownership rights, measured as entrepreneurial cash-flow rights; Control minus ownership, measured as the difference between entrepreneurial control rights and cash-flow rights. Industry and year dummies are also included but not reported. Pooled OLS regressions are applied and robust $t$ statistics are given in parentheses. All variables are winsorized at the top and bottom 5\%.***,**, and * denote significance at $1 \%, 5 \%$, and $10 \%$, respectively. 
Table 5. The value of entrepreneurial cash holdings (Continued)

\section{Panel A: GDP per capita}

In this panel, the institutions dummy is proxied by local GDP per capita, measured as above or below the sample median value of local average real GDP per capita during 1979-2007. If local GDP per capita in the provinces where the firm's headquarter is located is below the sample median value, the institutions proxy is equal to one and zero otherwise.

\begin{tabular}{|c|c|c|c|}
\hline & $\begin{array}{l}\text { (1) } \\
\text { Cash and cash } \\
\text { equivalents } \\
\text { to total assets }\end{array}$ & $\begin{array}{c}\text { (2) } \\
\text { Cash and cash } \\
\text { equivalents to total } \\
\text { assets minus cash } \\
\text { and cash equivalents }\end{array}$ & $\begin{array}{c}\text { (3) } \\
\text { Cash } \\
\text { to total assets }\end{array}$ \\
\hline Cash holdings & $\begin{array}{c}-1.645^{* * *} \\
(-2.68)\end{array}$ & $\begin{array}{c}-1.776^{* *} \\
(-2.26)\end{array}$ & $\begin{array}{c}-1.708 * * * \\
(-2.60)\end{array}$ \\
\hline Political participation & $\begin{array}{c}0.667 * * * \\
(2.90)\end{array}$ & $\begin{array}{c}0.553^{* * *} \\
(2.85)\end{array}$ & $\begin{array}{l}0.711^{* * *} \\
(3.07)\end{array}$ \\
\hline Institutions & $\begin{array}{l}-0.034 \\
(-0.18)\end{array}$ & $\begin{array}{l}-0.062 \\
(-0.38)\end{array}$ & $\begin{array}{l}-0.028 \\
(-0.15)\end{array}$ \\
\hline Cash holdings* & $2.793 * * *$ & $1.618 * * *$ & $3.144^{* * *}$ \\
\hline $\begin{array}{l}\text { Cash holdings* } \\
\text { institutions }\end{array}$ & $\begin{array}{l}0.811 \\
(0.84)\end{array}$ & $\begin{array}{l}0.537 \\
(0.94)\end{array}$ & $\begin{array}{l}0.888 \\
(0.89)\end{array}$ \\
\hline $\begin{array}{l}\text { Political participation* } \\
\text { institutions }\end{array}$ & $\begin{array}{l}0.538^{*} \\
(1.71)\end{array}$ & $\begin{array}{c}0.413^{* *} \\
(2.32)\end{array}$ & $\begin{array}{c}0.387^{* *} \\
(2.22)\end{array}$ \\
\hline $\begin{array}{l}\text { Cash holdings* } \\
\text { Political participation* }\end{array}$ & $\begin{array}{c}3.366 * * \\
(2.12)\end{array}$ & $\begin{array}{c}2.047 * * \\
(2.15)\end{array}$ & $\begin{array}{l}2.523 * * * \\
(2.59)\end{array}$ \\
\hline Institutions & & & \\
\hline Sales growth & $\begin{array}{c}0.482 * * * \\
(3.37)\end{array}$ & $\begin{array}{c}0.477 * * * \\
(3.34)\end{array}$ & $\begin{array}{l}0.494^{* * *} \\
(3.45)\end{array}$ \\
\hline Financial leverage & $\begin{array}{l}2.615^{* * *} \\
(7.24)\end{array}$ & $\begin{array}{l}2.676^{* * *} \\
(7.39)\end{array}$ & $\begin{array}{l}2.693 * * * \\
(7.46)\end{array}$ \\
\hline Firm size & $\begin{array}{c}-1.087 * * * \\
(-20.21)\end{array}$ & $\begin{array}{c}-1.088 * * * \\
(-20.22)\end{array}$ & $\begin{array}{c}-1.087 * * * \\
(-20.20)\end{array}$ \\
\hline Profitability & $\begin{array}{l}22.531 * * * \\
(16.55)\end{array}$ & $\begin{array}{l}22.411 * * * \\
(16.46)\end{array}$ & $\begin{array}{c}22.380 * * * \\
(16.43)\end{array}$ \\
\hline Ownership rights & $\begin{array}{c}0.666^{* *} \\
(2.24)\end{array}$ & $\begin{array}{c}0.659 * * \\
(2.22)\end{array}$ & $\begin{array}{c}0.639 * * \\
(2.15)\end{array}$ \\
\hline Control minus ownership & $\begin{array}{l}-0.748 \\
(-0.57)\end{array}$ & $\begin{array}{l}-0.739 \\
(-0.55)\end{array}$ & $\begin{array}{l}-0.697 \\
(-0.46)\end{array}$ \\
\hline Intercept & $\begin{array}{l}25.742 * * * \\
(22.57)\end{array}$ & $\begin{array}{l}25.697 * * * \\
(22.54)\end{array}$ & $\begin{array}{l}25.750 * * * \\
(22.55)\end{array}$ \\
\hline Industry indicator & Yes & Yes & Yes \\
\hline Year indicator & Yes & Yes & Yes \\
\hline $\begin{array}{l}\text { Observations } \\
\text { Adiusted } R^{2}\end{array}$ & $\begin{array}{l}2115 \\
0.230\end{array}$ & $\begin{array}{l}2115 \\
0.229\end{array}$ & $\begin{array}{l}2115 \\
0.229\end{array}$ \\
\hline
\end{tabular}


Table 5. The value of entrepreneurial cash holdings (Continued)

\section{Panel B: Marketization}

In this panel, the institutions dummy is proxied by whether or not the firm's headquarter is located in a relatively more developed region, using the National Economic Research Institute (NERI) Index of Marketization for China's provinces. If the firm's headquarter is located in a less developed region, the institutions dummy is equal to one and zero otherwise.

\begin{tabular}{|c|c|c|c|}
\hline & $\begin{array}{l}\text { (1) } \\
\text { Cash and cash } \\
\text { equivalents } \\
\text { to total assets }\end{array}$ & $\begin{array}{c}\text { (2) } \\
\text { Cash and cash } \\
\text { equivalents to total } \\
\text { assets minus cash } \\
\text { and cash equivalents }\end{array}$ & $\begin{array}{c}\text { (3) } \\
\text { Cash } \\
\text { to total assets }\end{array}$ \\
\hline Cash holdings & $\begin{array}{c}-1.990 * * * \\
(-3.03)\end{array}$ & $\begin{array}{c}-1.997 * * * \\
(-2.68)\end{array}$ & $\begin{array}{c}-1.995 * * * \\
(-2.86)\end{array}$ \\
\hline Political participation & $\begin{array}{l}0.654 * * * \\
(2.75)\end{array}$ & $\begin{array}{c}0.538 * * * \\
(2.68)\end{array}$ & $\begin{array}{c}0.690 * * * \\
(2.89)\end{array}$ \\
\hline Institutions & $\begin{array}{l}-0.033 \\
(-0.18)\end{array}$ & $\begin{array}{l}-0.071 \\
(-0.44)\end{array}$ & $\begin{array}{l}-0.040 \\
(-0.22)\end{array}$ \\
\hline Cash holdings* & $3.148 * * *$ & $1.871^{* * *}$ & $3.453 * * *$ \\
\hline Political participation & $(2.73)$ & $(2.77)$ & $(2.91)$ \\
\hline $\begin{array}{l}\text { Cash holdings* } \\
\text { institutions }\end{array}$ & $\begin{array}{l}1.285 \\
(1.40)\end{array}$ & $\begin{array}{c}0.817 \\
(0.817)\end{array}$ & $\begin{array}{l}1.275 \\
(1.32)\end{array}$ \\
\hline $\begin{array}{l}\text { Political participation* } \\
\text { institutions }\end{array}$ & $\begin{array}{c}0.465^{* *} \\
(2.31)\end{array}$ & $\begin{array}{c}0.339 * * \\
(2.30)\end{array}$ & $\begin{array}{c}0.313^{* *} \\
(2.33)\end{array}$ \\
\hline Cash holdings* & $3.652 * *$ & $2.230 * *$ & $2.830 *$ \\
\hline $\begin{array}{l}\text { Political participation* } \\
\text { institutions }\end{array}$ & (2.33) & (2.39) & $(1.75)$ \\
\hline Sales growth & $\begin{array}{c}0.480 * * * \\
(3.36)\end{array}$ & $\begin{array}{c}0.476 * * * \\
(3.33)\end{array}$ & $\begin{array}{c}0.492 * * * \\
(3.44)\end{array}$ \\
\hline Financial leverage & $\begin{array}{l}2.624 * * * \\
(7.27)\end{array}$ & $\begin{array}{l}2.686 * * * \\
(7.42)\end{array}$ & $\begin{array}{l}2.710 * * * \\
(7.52)\end{array}$ \\
\hline Firm size & $\begin{array}{c}-1.084 * * * \\
(-20.25)\end{array}$ & $\begin{array}{c}-1.087 * * * \\
(-20.27)\end{array}$ & $\begin{array}{c}-1.086^{* * * *} \\
(-20.26)\end{array}$ \\
\hline Profitability & $\begin{array}{l}22.479 * * * \\
(16.54)\end{array}$ & $\begin{array}{l}22.361 * * * \\
(16.44)\end{array}$ & $\begin{array}{l}22.313^{* * * *} \\
(16.40)\end{array}$ \\
\hline Ownership rights & $\begin{array}{c}0.692 * * \\
(2.33)\end{array}$ & $\begin{array}{c}0.686^{* *} \\
(2.31)\end{array}$ & $\begin{array}{c}0.655^{* *} \\
(2.21)\end{array}$ \\
\hline Control minus ownership & $\begin{array}{l}-0.738 \\
(-0.55)\end{array}$ & $\begin{array}{l}-0.732 \\
(-0.54)\end{array}$ & $\begin{array}{l}-0.681 \\
(-0.43)\end{array}$ \\
\hline Intercept & $\begin{array}{l}25.703 * * * \\
(22.67)\end{array}$ & $\begin{array}{l}25.665^{* * *} \\
(22.64)\end{array}$ & $\begin{array}{l}25.735 * * * \\
(22.64)\end{array}$ \\
\hline Industry indicator & Yes & Yes & Yes \\
\hline Year indicator & Yes & Yes & Yes \\
\hline $\begin{array}{l}\text { Observations } \\
\text { Adjusted } R^{2}\end{array}$ & $\begin{array}{l}2115 \\
0.230\end{array}$ & $\begin{array}{l}2115 \\
0.230\end{array}$ & $\begin{array}{l}2115 \\
0.230\end{array}$ \\
\hline
\end{tabular}


Table 5. The value of entrepreneurial cash holdings (Continued)

\section{Panel C: Property protection}

In this panel, the institutions dummy is proxied by whether or not the firm's headquarter is located in a province that has a higher level of property protection based on a World Bank field survey (World Bank, 2006). If the firm's headquarter is located in a province that has a lower level of property protection, the institutions dummy is equal to one and zero otherwise.

\begin{tabular}{|c|c|c|c|}
\hline & $\begin{array}{l}\text { (1) } \\
\text { Cash and cash } \\
\text { equivalents } \\
\text { to total assets }\end{array}$ & $\begin{array}{c}\text { (2) } \\
\text { Cash and cash } \\
\text { equivalents to total } \\
\text { assets minus cash } \\
\text { and cash equivalents }\end{array}$ & $\begin{array}{c}\text { (3) } \\
\text { Cash } \\
\text { to total assets }\end{array}$ \\
\hline Cash holdings & $\begin{array}{c}-1.317 * * \\
(-2.20)\end{array}$ & $\begin{array}{l}-1.529 * \\
(-1.75)\end{array}$ & $\begin{array}{c}-1.273^{* *} \\
(-2.02)\end{array}$ \\
\hline Political participation & $\begin{array}{c}0.423^{* *} \\
(1.99)\end{array}$ & $\begin{array}{c}0.370^{* * *} \\
(2.05)\end{array}$ & $\begin{array}{l}0.594 * * * \\
(2.78)\end{array}$ \\
\hline Institutions & $\begin{array}{l}-0.227 \\
(-0.20)\end{array}$ & $\begin{array}{l}-0.267 \\
(-0.64)\end{array}$ & $\begin{array}{l}-0.234 \\
(-0.23)\end{array}$ \\
\hline Cash holdings* & $1.427 * *$ & $0.858 * *$ & $2.470 * *$ \\
\hline Political participation & $(2.53)$ & $(2.45)$ & $(2.32)$ \\
\hline $\begin{array}{l}\text { Cash holdings* } \\
\text { institutions }\end{array}$ & $\begin{array}{l}-0.196 \\
(-0.20)\end{array}$ & $\begin{array}{l}-0.301 \\
(-0.54)\end{array}$ & $\begin{array}{l}-0.297 \\
(-0.29)\end{array}$ \\
\hline $\begin{array}{l}\text { Political participation* } \\
\text { institutions }\end{array}$ & $\begin{array}{c}0.129 * * \\
(2.41)\end{array}$ & $\begin{array}{c}0.086^{* *} \\
(2.32)\end{array}$ & $\begin{array}{c}0.224^{* * *} \\
(0.224)\end{array}$ \\
\hline Cash holdings* & $0.640 * *$ & $0.338 * * *$ & $0.674^{*}$ \\
\hline $\begin{array}{l}\text { Political participation* } \\
\text { institutions }\end{array}$ & (2.38) & $(2.97)$ & $(0.71)$ \\
\hline Sales growth & $\begin{array}{l}0.509 * * * \\
(3.56)\end{array}$ & $\begin{array}{c}0.505^{* * *} \\
(3.53)\end{array}$ & $\begin{array}{c}0.516 * * * \\
(3.61)\end{array}$ \\
\hline Financial leverage & $\begin{array}{l}2.628 * * * \\
(7.27)\end{array}$ & $\begin{array}{l}2.686 * * * \\
(7.41)\end{array}$ & $\begin{array}{l}2.731^{* * *} \\
(7.56)\end{array}$ \\
\hline Firm size & $\begin{array}{c}-1.099 * * * \\
(-20.65)\end{array}$ & $\begin{array}{c}-1.101^{* * * *} \\
(-20.68)\end{array}$ & $\begin{array}{c}-1.099 * * * \\
(-20.69)\end{array}$ \\
\hline Profitability & $\begin{array}{l}22.532 * * * \\
(16.54)\end{array}$ & $\begin{array}{l}22.451 * * * \\
(16.47)\end{array}$ & $\begin{array}{l}22.393^{* * * *} \\
(16.44)\end{array}$ \\
\hline Ownership rights & $\begin{array}{c}0.686 * * \\
(2.30)\end{array}$ & $\begin{array}{c}0.683^{* *} \\
(2.29)\end{array}$ & $\begin{array}{c}0.671^{* *} \\
(2.26)\end{array}$ \\
\hline Control minus ownership & $\begin{array}{l}-0.697 \\
(-0.46)\end{array}$ & $\begin{array}{l}-0.675 \\
(-0.41)\end{array}$ & $\begin{array}{c}-0.662 \\
(-0.662)\end{array}$ \\
\hline Intercept & $\begin{array}{l}25.887 * * * \\
(23.18)\end{array}$ & $\begin{array}{l}25.848 * * * \\
(23.14)\end{array}$ & $\begin{array}{l}25.891 * * * \\
(23.19)\end{array}$ \\
\hline Industry indicator & Yes & Yes & Yes \\
\hline Year indicator & Yes & Yes & Yes \\
\hline $\begin{array}{l}\text { Observations } \\
\text { Adjusted } R^{2}\end{array}$ & $\begin{array}{l}2115 \\
0.229\end{array}$ & $\begin{array}{l}2115 \\
0.229\end{array}$ & $\begin{array}{l}2115 \\
0.230\end{array}$ \\
\hline
\end{tabular}

